\title{
Subcellular quantification of uptake in Gram-negative bacteria
}

\author{
Hans Prochnow ${ }^{1}$, Verena Fetz ${ }^{1,2}$, Sven-Kevin Hotop ${ }^{1}$, Mariel A. García-Rivera ${ }^{1}$, \\ Axel Heumann ${ }^{1}$, Mark Brönstrup ${ }^{1,3^{*}}$
}

1 Department of Chemical Biology, Helmholtz Centre for Infection Research and German Centre for Infection Research (DZIF), Inhoffenstraße 7, 38124 Braunschweig, Germany

2 School of Engineering and Science, Jacobs University Bremen, Germany

3 German Center for Infection Research (DZIF), Inhoffenstraße 7, 38124 Braunschweig, Germany

* correspondence to mark.broenstrup@helmholtz-hzi.de

\begin{abstract}
Infections by Gram-negative pathogens represent a major health care issue of growing concern due to a striking lack of novel antibacterial agents over the course of the last decades. The main scientific problem behind the rational optimization of novel antibiotics is our limited understanding of small molecule translocation into, and their export from the target compartments of Gram-negative species. To address this issue, a versatile, label-free assay to determine the intracellular localization and concentration of a given compound has been developed for Escherichia coli and its effluximpaired $\Delta$ TolC mutant. The assay applies a fractionation procedure to antibiotic-treated bacterial cells to obtain periplasm, cytoplasm and membrane fractions of high purity, as demonstrated by Western Blots of compartment-specific marker proteins. This is followed by an LC-MS/MS-based quantification of antibiotic content in each compartment. Antibiotic amounts could be converted to antibiotic concentrations by assuming that an $E$. coli cell is a cylinder flanked by two half spheres and calculating the volumes of bacterial compartments. The quantification of antibiotics from different classes, namely ciprofloxacin, tetracycline, trimethoprim and erythromycin demonstrated pronounced differences in uptake quantities and distribution patterns across the compartments. For example, in the case of ciprofloxacin a higher amount of compound was located in the cytoplasm than in the periplasm (592 pg $\pm 50 \mathrm{pg}$ vs $277 \pm 13 \mathrm{pg}$ per $3.9 \times 10^{9}$ cells), but owing to the smaller volume of the periplasmic compartment, its concentration in the cytoplasm was much lower ( $37 \pm 3 \mathrm{pg} / \mu \mathrm{l}$ vs. $221 \pm 10 \mathrm{pg} / \mu \mathrm{l}$ for the periplasm). For erythromycin and tetracycline, differences in MICs between WT and $\triangle$ TolC mutant strains were not reflected by equal differences in uptake, illustrating that additional experimental data are needed to predict antibiotic efficacy. We believe that our assay, providing the antibiotic concentration at the compartment in which the drug target is expressed, constitutes an essential piece of information for a more rational optimization of novel antibiotics against Gram-negative infections.
\end{abstract}




\section{Introduction}

Bacterial infections represent a major health care issue due to an alarming combination of increasing resistance to antibiotics and a concomitant decrease of novel antibacterial agents ${ }^{1}$. The WHO has therefore defined a list of priority pathogens with the highest unmet medical needs recently ${ }^{2}$. Remarkably, many entries from the top tiers of the list are Gram-negative bacteria, in particular drugresistant Acinetobacter baumannii, Pseudomonas aeruginosa and Enterobacteriaceae. These organisms are sheltered from the environment by a bacterial cell wall composed of an inner membrane (IM) and an outer membrane (OM), which encompass the periplasmic space (PP) with the peptidoglycan layer. The $\mathrm{OM}$ has an asymmetric structure with an inner leaflet composed of phospholipids and an outer leaflet being interspersed with tightly packed lipopolysaccharides (LPS). As such, the OM is a barrier for hydrophilic molecules and is less permeable to lipophilic solutes than a normal symmetric phospholipid bilayer ${ }^{3-5}$. Compound uptake is believed to occur primarily by passive diffusion through porins, $\beta$-barrel-shaped proteins embedded in the OM with a preference for polar molecules with molecular weights $<600 \mathrm{Da})^{5-8}$ or by active transport mediated by TonBdependent transporters ${ }^{9-10}$. In addition, also protein-free membrane diffusion needs to be considered, as this mechanism was found to be operative for antibiotics like aminoglycosides, cationic peptides and other classes ${ }^{5,7,11}$. However, the scientific understanding of drug researchers how to design molecules that can efficiently permeate the Gram-negative cell walls and escape efflux mechanisms ${ }^{12-13}$ is insufficient. Because two in-depth analysis from industry have demonstrated that the antibacterial potency of small molecule hits often remains too low in Gram-negative bacteria in spite of potent inhibition of the molecular target under in vitro conditions, the drug translocation problem is regarded as the main cause of an alarmingly thin pipeline of novel antibiotics against Gram-negative bacteria ${ }^{14-16}$. Thus, the rational optimization of novel antibiotics would massively benefit from information on the concentration of a drug in the target compartment, which constitutes a missing link between target inhibition strength and antibacterial potency.

In consequence, a variety of assays for quantification of compound internalization into bacteria have been developed (Supplementary Table S1) ${ }^{17-18}$. Many of them depend on introducing a label like a fluorescent or fluorogenic moiety or radioactive/heavy isotopes and are therefore hardly applicable to series of hit molecules in an early discovery stage. Microbiological methods based on growth measurements derive indirect evidence from genetic mutants with altered import or export properties. Arguably, the most versatile techniques are based on a mass spectrometric detection of unmodified molecules. A high special resolution could be achieved by C60-Secondary lon Mass Spectrometry (SIMS) ${ }^{19}$. First liquid chromatography coupled to mass spectrometry (LC-MS)-based methods have been reported by Cai et al., Phetsang et al., Davis et al. and Bhat et al. ${ }^{20-23}$. Recently, Richter et al. have derived a set of physicochemical and structural rules for improved compound accumulation based on LC-MS measurements ${ }^{24}$. However, those LC-MS methods measure the total cellular amount of drug and do not distinguish between subcellular compartments, a limitation highlighted in a recent study by lyer et al. ${ }^{25}$. We hypothesized that the drug concentrations in the compartments can differ substantially due to distinct physicochemical properties or the barrier that separates cytoplasm from periplasm.

We therefore developed an assay to quantify the amount of small molecules in the cytoplasm, the periplasm or the membranes of Escherichia coli cells. It combines the subfractionation of antibiotic- 
treated bacteria with an LC-MS/MS-based quantification of the antibiotic content in the respective subfractions. Based on literature data for dimensions of subcellular compartments, the antibiotic quantities are converted to concentration data. The latter information is important for structureactivity-relationship (SAR) studies, as it can be directly linked to inhibitory concentration $\left(\mathrm{IC}_{50}\right)$ data at a given molecular target. The additional insights obtained by the assay and its limitations are demonstrated by four standard antibiotics.

\section{Material \& Methods}

\section{Bacterial strains and chemicals}

E. coli K12-BW25113 (wildtype) and E. coli K-12 JW5503-1 ( $\triangle$ TolC, derived from BW25113) were obtained from the Coli Genetic Stock Center (CGSC) and cultivated in LB medium. $50 \mu \mathrm{g} / \mathrm{ml}$ Kanamycin were added to cultures of E. coli $\triangle$ TolC. Ciprofloxacin (CIP) and Tetracycline were dissolved in $0.1 \mathrm{M}$ formic acid. Erythromycin was dissolved in DMSO. All chemicals were obtained from Sigma-Aldrich (St. Louis, Missouri, USA).

\section{Treatment with antibiotics}

Overnight cultures of bacteria were diluted to an $\mathrm{OD}_{600 \mathrm{~nm}}$ of 0.1 in LB-medium and grown until an $\mathrm{OD}_{600 \mathrm{~nm}}$ of $0.8 \mathrm{in}$ baffled flasks. Of these, $10 \mathrm{ml}$ were dispensed to $15-\mathrm{ml}$ Falcon tubes, and antibiotic $(100 \mathrm{ng} / \mathrm{ml})$ or solvent-control was added. If not stated otherwise, samples were incubated at $37^{\circ} \mathrm{C}$, while shaking at $170 \mathrm{rpm}$, and incubation times were set to $10 \mathrm{~min}$. Hereafter, the $O D_{600 \mathrm{~nm}}$ of the suspension was again recorded for later calculations and samples were split: $5 \mathrm{ml}$ of suspension were subjected to subcellular fractionation, and $5 \mathrm{ml}$ were used for generating whole cell lysates. Bacterial cells were collected by centrifugation $(4500 \times \mathrm{g}, 5 \mathrm{~min})$.

\section{Subcellular fractionation}

To release periplasmic contents, a well-established and efficient method based on cold osmotic shock was applied ${ }^{26-27}$. Pelleted bacteria were washed and resuspended in $1 \mathrm{ml}$ TBS (50 mM Tris, [pH 7.4], $150 \mathrm{mM} \mathrm{NaCl}$ ) and transferred to a $2 \mathrm{ml}$ Eppendorf tube. Following another washing step with $300 \mu \mathrm{l}$ of $25 \mathrm{mM}$ Tris [pH 7.4], bacteria were resuspended in $100 \mu \mathrm{l} 25 \mathrm{mM}$ Tris, and $100 \mu \mathrm{l}$ of SE-buffer (25 mM Tris, [pH 7.4], 40\% (w/w) sucrose, 2 mM EDTA) was slowly added. Liquid phases were mixed by gently tapping the tube and the mixture was incubated at room temperature for $5 \mathrm{~min}$. Hereafter, bacteria were pelleted $(3,500 \times \mathrm{g}, 5 \mathrm{~min})$, supernatant was carefully discarded and pellets were overlaid with $200 \mu$ l TS-buffer ( $25 \mathrm{mM}$ Tris, [pH 7.4], 20\% (w/w) sucrose). Samples were again centrifuged $(3,500 \times \mathrm{g}, 1 \mathrm{~min})$ and supernatant was discarded. Then, $200 \mu$ l of hypoosmotic solution $\left(0.5 \mathrm{mM} \mathrm{MgSO}_{4}\right.$, pre-cooled to $4^{\circ} \mathrm{C}$ ) was added, and pellets were soaked for $10 \mathrm{~min}$ on ice. This releases the periplasmic fraction, which was separated by centrifugation $(3,500 \times \mathrm{g}, 10 \mathrm{~min})$ and recovered. The remaining cells were vigorously resuspended in $190 \mu \mathrm{l}$ of $10 \mathrm{mM}$ Tris [pH 7.4] and subjected to ultrasound using a Sonoplus sonifier [Bandelin] equipped with a MS 2.5 tip. Two $30 \mathrm{~s}$ long pulses corresponding to $1.0 \mathrm{~kJ}$ were applied to liberate the cytoplasmic contents, while samples were cooled on ice. Next, $10 \mu \mathrm{l}$ of DNase-mix ( $1 \mathrm{M} \mathrm{MgCl}_{2}, 50 \mu \mathrm{g} / \mathrm{ml}$ DNasel) were added, and samples were incubated for $15 \mathrm{~min}$ at $37^{\circ} \mathrm{C}$. Finally, the membranous fraction was separated by high-speed centrifugation $(30,000 \times \mathrm{g}, 45 \mathrm{~min})$. The supernatant, which contained the cytoplasmic fraction, was 
recovered and the membranous pellet was resuspended in $200 \mu \mathrm{l} 0.5 \mathrm{mM} \mathrm{MgSO}_{4}$. All fractions were stored at $4^{\circ} \mathrm{C}$ and processed within $24 \mathrm{~h}$. The data presented come from at least 3 biological replicates. Each replicate was generated from a separate flask of freshly grown bacteria, as described above. No technical replicates were measured.

\section{Generation of whole cell lysates}

Samples were initially as described for subcellular fractionation until incubation with TS-buffer. Thereafter, the bacterial pellet was resuspended in $190 \mu \mathrm{l} 10 \mathrm{mM}$ Tris [pH 7.4] and directly subjected to sonication. After addition of $10 \mu \mathrm{l}$ of DNase-mix and subsequent incubation for $15 \mathrm{~min}$ at $37^{\circ} \mathrm{C}$, whole cell lysates (WC) were stored at $4^{\circ} \mathrm{C}$ and processed within $24 \mathrm{~h}$. The data presented come from at least 3 biological replicates. Each replicate was generated from a separate flask of freshly grown bacteria, as described above. No technical replicates were measured.

\section{Western blot}

Protein concentrations were determined by a Bradford assay. For Western blot analysis, $4 \mu \mathrm{g}$ of either subcellular fractions or whole cell lysates were subjected to SDS-PAGE. Gels contained 1\% (v/v) 2,2,2-Trichloroethanol, enabling stain-free detection of protein-bands after electrophoresis ${ }^{28}$. Gels were blotted onto PVDF membranes, which were subsequently blocked in PBS containing $5 \%(\mathrm{w} / \mathrm{w})$ dry-milk powder. Membranes were then cut horizontally to allow for separate incubation with the following detection antibodies: anti-GroEL [ADI-SPS-870-D, Enzo Life Sciences], anti-maltose binding protein (MBP) [GTX124267, GeneTex] and anti-outer membrane porin A (OmpA) [111120, Antibody Research Corporation]. Secondary antibodies coupled to HRP were applied, and the HRP-activity was monitored with Clarity ${ }^{\mathrm{TM}}$ ECL Western blotting substrate and a ChemiDoc XRS (BioRad, Hercules, CA, USA). Signal intensities were quantified with the Image Lab software (BioRad, Hercules, CA, USA)

\section{Sample preparation and LC-MS analysis}

$80 \mu \mathrm{l}$ of either subcellular fractions or whole cell lysates were mixed with $80 \mu \mathrm{l}$ formic acid $(0.1 \mathrm{M})$ and $240 \mu \mathrm{l}$ acetonitrile/methanol (1:1). For erythromycin-containing samples, $\mathrm{H}_{2} \mathrm{O}$ instead of formic acid was added. Samples were mixed in a 96-deep well plate and centrifuged $\left(2,500 \times \mathrm{g}, 60 \mathrm{~min}, 4^{\circ} \mathrm{C}\right)$. Hereafter, $320 \mu \mathrm{l}$ of supernatant were transferred to a 96-well V-shaped plate and dried by vacuum centrifugation in a Refigerated CentriVap with $-50^{\circ} \mathrm{C}$ Cold Trap (Labconco, Kansas, MO, USA). Dried pellets were resolved in a volume of $40 \mu \mathrm{l}$ containing $10 \mathrm{ng} / \mathrm{ml}$ caffeine as an internal standard. Processed samples were analyzed on an Agilent 1290 UHPLC (Agilent Technologies, Santa Clara, CA, USA) coupled to an AB Sciex QTrap 6500 triple quadrupole mass spectrometer (AB Sciex Germany GmbH, Darmstadt, Germany).

LC separations were achieved with a ZORBAX Eclipse Plus C18 2.1x50mm 1.8-Micron column, equipped with a guard column (ZORBAX $2.1 \times 5 \mathrm{~mm}$; both from Agilent Technologies, Santa Clara, CA, USA). A linear gradient using solvent $A\left(\mathrm{H}_{2} \mathrm{O}+0.1 \%\right.$ formic acid) and solvent $B$ (acetonitrile $+0.1 \%$ formic acid) was applied from $1 \% B$ to $99 \% B$ within $5 \mathrm{~min}$ at a constant flow of $0.7 \mathrm{ml} / \mathrm{min}$. A MRM (multiple reaction monitoring) method was applied, which allowed for a sensitive detection of the compound of interest. The Q1/Q3-transition masses used for compound identification are listed in 
Supplementary Table S3. Peak areas of quantifier peaks were determined and used for calculations. Standard curves were obtained by measuring bacterial fractions with spiked-in, predefined concentrations of antibiotic. The integrated peak areas ( $y$-axis) were then plotted over antibiotic concentration in $\mathrm{ng} / \mathrm{ml}$ (x-axis), and a linear regression analysis was performed. Based on the regression curve, the antibiotic concentration in test samples was determined.

\section{Minimum inhibitory concentrations (MIC)}

All bacterial cultures were prepared in Mueller-Hinton broth (Carl Roth, Germany). Overnight cultures of $E$. coli (wildtype or $\triangle \mathrm{TolC}$ ) were diluted and grown to $\mathrm{OD}_{600 \mathrm{~nm}}=0.5$. These were then diluted to $\mathrm{OD}_{600 \mathrm{~nm}}=0.01$ and subjected to MIC-determination. Test compounds were serially diluted (3-fold) in respective solvent. Eleven dilution steps were applied, and plain solvent served as an untreated control. Compound dilutions were added to bacterial cultures in a 96-well culture plate to give a final volume of $150 \mu$ l. Compound dilutions were also added to plain Mueller-Hinton broth to serve as a blank control. Plates were incubated at $37^{\circ} \mathrm{C}$ for $18 \mathrm{~h}$, and $\mathrm{OD}_{600 \mathrm{~nm}}$ was determined in a plate spectrophotometer. All values were corrected by subtracting the values obtained from respective blank controls. Then, results were expressed as \%-growth relative to untreated controls and plotted on an $\mathrm{x} / \mathrm{y}$-graph over concentration $\left(\log _{10}\right)$. MIC-calculations were performed with GraphPad Prism by applying a non-linear regression with a modified Gompertz function ${ }^{29}$. 


\section{Results}

\section{Subcellular fractionation of E. coli}

We have set up a workflow to generate subcellular fractions of $E$. coli cells. In addition to a wildtype (WT) strain (E. coli K12-BW25113), a mutant strain being deficient in the AcrAB-TolC efflux system $(\triangle T$ olC) was investigated to capture the role of efflux. For the initial studies, the fluoroquinolone ciprofloxacin (CIP) was selected as a reference compound and added to the bacterial cultures at $100 \mathrm{ng} / \mathrm{ml}$ for $10 \mathrm{~min}$. To avoid bactericidal effects that would falsify uptake measurements, the CIP concentration and the incubation time were kept low. At the indicated parameters, we observed only a marginal drop in bacterial viability, as indicated by CFU counts (Supplementary Figure S1). Fractionation of subcellular bacterial compartments was performed by following a procedure based on cold osmotic shock. After incubating the cells with EDTA/sucrose-containing hyperosmotic buffer, an osmotic shock was induced by addition of a hypoosmotic $\mathrm{MgSO}_{4}$ solution. This releases the periplasmic fraction (PP), which was separated by low-speed centrifugation. The cytosolic fraction (CP) was obtained by ultrasonication and separated from the membranous fraction (M) by highspeed centrifugation (Figure 1). In parallel, lysates of unfractionated bacteria were prepared (WC).

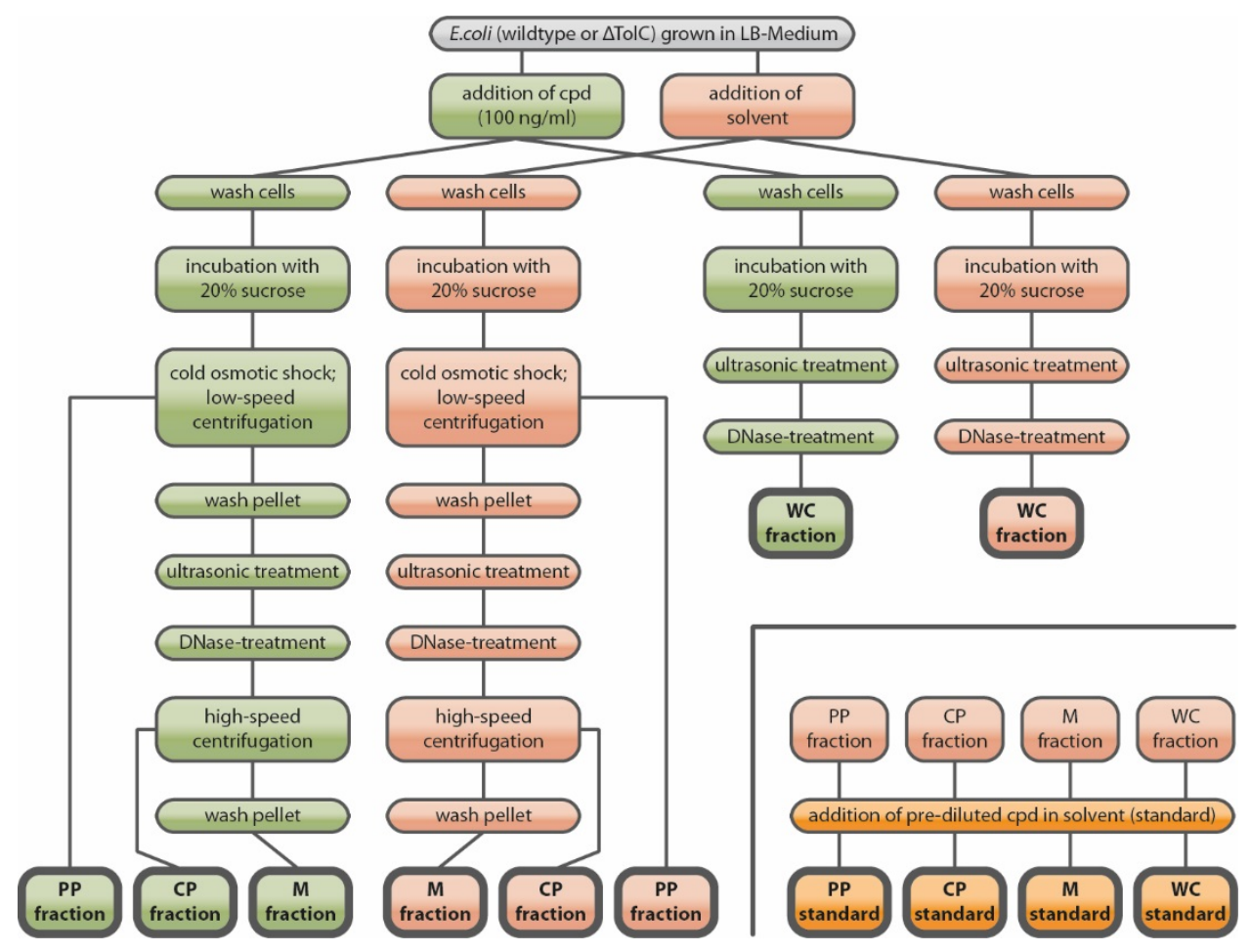

Figure 1: Experimental workflow. E. coli cells were either treated with compound (cpd, green boxes) or mock-treated with solvent (red boxes). Samples obtained from the latter were submitted as blankcontrols to LC-MS, or used to generate LC-MS standard curves. For the latter purpose, subcellular fractions (PP, CP, M) or whole cell lysates (WC) obtained from solvent-treated cells were spiked with 3-fold serial dilutions of compound prepared in solvent (orange boxes). Final concentrations of standards were $100 \mathrm{ng} / \mathrm{ml}, 33.33 \mathrm{ng} / \mathrm{ml}, 11.11 \mathrm{ng} / \mathrm{ml}, 3.70 \mathrm{ng} / \mathrm{ml}, 1.23 \mathrm{ng} / \mathrm{ml}$ and $0.41 \mathrm{ng} / \mathrm{ml}$, respectively. Bold-framed boxes denote samples that were processed for LC-MS to quantify the concentration/amount of compound. 
The quality of fractionation was assessed via Western blot analyses by using antibodies directed against compartment-specific proteins (Figure 2a). Maltose binding protein (MBP) served as a marker for the PP, the chaperone GroEL as a marker for the $\mathrm{CP}$ and the outer membrane porin $\mathrm{A}(\mathrm{OmpA})$ as a marker for the membranous fraction $M^{30-32}$. The relative purity of each fraction was estimated through densitometric quantification of Western blot signals by a software-based image analysis (Figure $2 \mathrm{~b}$ ). The sum of band intensities of a given marker protein across all fractions was set to $100 \%$, and the proportion of the band intensity in each individual fraction was calculated. MBP was exclusively found in the PP in both untreated and CIP-treated WT cells, whereas slight carryovers to the CP (4\%) were observed for the CIP-treated $\triangle$ TolC mutant. Of the cytoplasmic marker GroEL we found $71 \%$ in the CP of untreated bacteria and $66 \%-69 \%$ in the CP of CIP-treated cells. We could not avoid carryovers to the $M$ fraction $(22 \%-25 \%)$ and to the PP $(4 \%-12 \%)$, whereas the latter contamination was more pronounced in CIP-treated $\triangle$ TolC mutant cells. 90-92\% of the membrane marker OmpA was found in the M fraction of wildtype cells with only minor carryover to the PP $(8 \%-$ $10 \%)$. However, in the CIP-treated samples of the $\Delta$ TolC mutant more prominent carryovers to the PP and CP occurred (20\% and $2 \%$ respectively). The experiments demonstrate that the subcellular fractionation protocol leads to a high purity PP and $M$ fractions, and a significantly enriched $C P$ fraction according to the protein markers. Importantly, the fractionation efficiency is almost retained under treatment with a potent, bactericidal antibiotic.
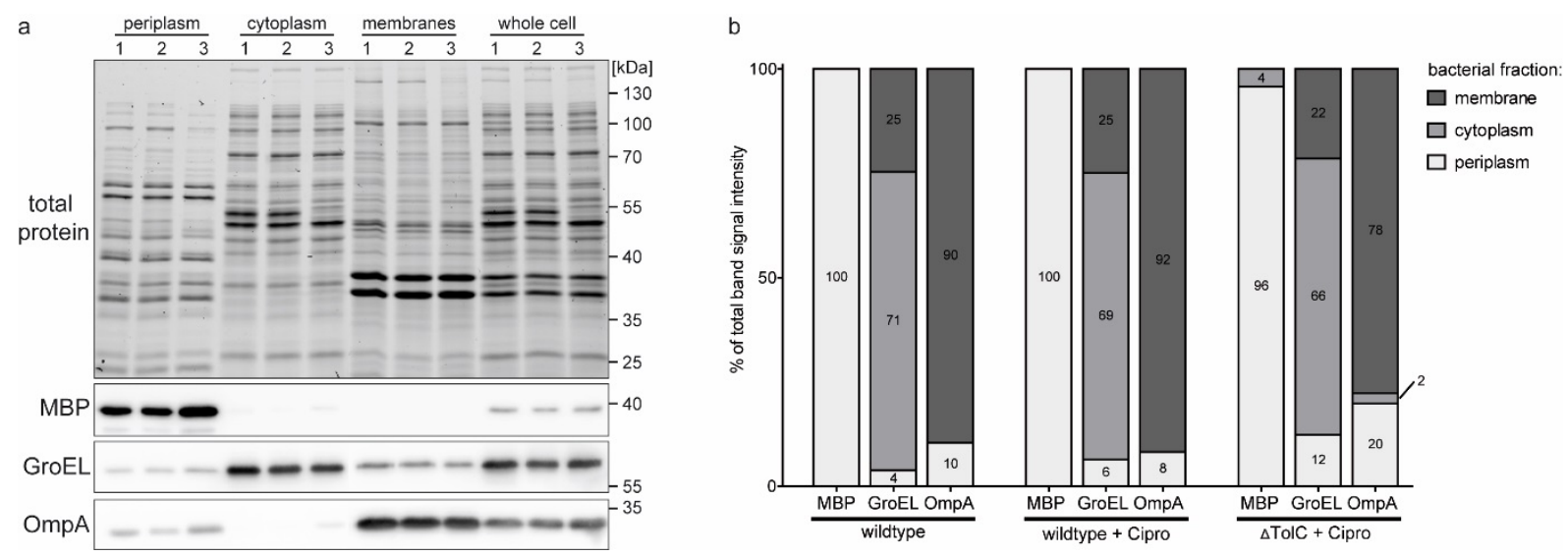

Figure 2: Fractionation efficiency assessed by Western blot. (A) E. coli cultures at $\mathrm{OD}_{600 \mathrm{~nm}}$ of 0.8 were subjected to $100 \mathrm{ng} / \mathrm{ml} \mathrm{CIP}$ for $10 \mathrm{~min}$. Solvent-treated wildtype (1), CIP-treated wildtype (2) or CIPtreated $\triangle T$ TolC E. coli (3) were processed for fractionation. Subsequently, $5 \mu \mathrm{g}$ of total protein of the respective fractions (PP, CP; M) or of un-fractionated bacteria (whole cell, WC) was loaded on SDSPAGE. 2,2,2-Trichlorethanol-mediated total protein staining of the gel illustrates the fractionation process. The gel was blotted and subjected to MBP-, GroEL- and OmpA-specific antibodies to detect respective marker proteins. (B) Densitometric analysis of the Western blot signals from (A). The sum of band intensities of each marker protein (MBP; GroEL or OmpA) across all fractions was set to $100 \%$. Then the proportion of the band intensity in each individual fraction was calculated for the indicated treatments. 


\section{Quantification of antibiotic uptake}

The fractions obtained from the bacteria were mixed with an excess of acetonitrile and methanol to denature proteins and to disrupt non-covalent interactions of the antibiotics with macromolecules. After centrifugation, drying and solvation, the fractions were subjected to LC-MS to quantify the respective amounts of antibiotic. The amount of antibiotic in the total volume of each fraction $(200 \mu \mathrm{l})$ was calculated as followed: We assumed that $1 \mathrm{ml}$ LB-culture of E. coli BW25113 at an $\mathrm{OD}_{600 \mathrm{~nm}}$ of 1 corresponds to $7.8 \times 10^{8}$ cells ${ }^{33}$, thus $5 \mathrm{ml}$ of culture contain $3.9 \times 10^{9}$ cells. Accordingly, we normalized the values obtained in our approach to $3.9 \times 10^{9}$ cells based on the $\mathrm{OD}_{600 \mathrm{~nm}}$ of the sample cultures determined after antibiotic incubation. In order to avoid quantification errors by (unspecific) matrix interactions, all calibration curves were prepared in compartment-specific matrices (Figure 1 and Supplementary Figure S2). While a matrix effect was not observed for trimethoprim and less than 2 fold differences were found for ciprofloxacin and erythromycin, substantially different (7fold) MS responses were detected for tetracycline in the different matrices. This underlines the importance of MS-calibrations in the correct respective matrices.

Eventually, we were interested in the concentration of internalized compound in the distinct bacterial compartments. To calculate this, the volumes occupied by PP, CP as well as inner (IM) and outer membranes (OM) were approximated by considering an $E$. coli cell as a cylinder flanked by two hemispheres (Figure 3A) with geometrical data reported in the literature ${ }^{34-35}$. The dimensions of an E. coli cell have been studied by cryo-transmission electron microscopy ${ }^{36}$ and fluorescence microscopy ${ }^{33}$ and are summarized in Figure 3B-C. Based on these assumptions, the volumes for $\mathrm{CP}$, IM, PP and OM were calculated as depicted in Figure 3D.

A

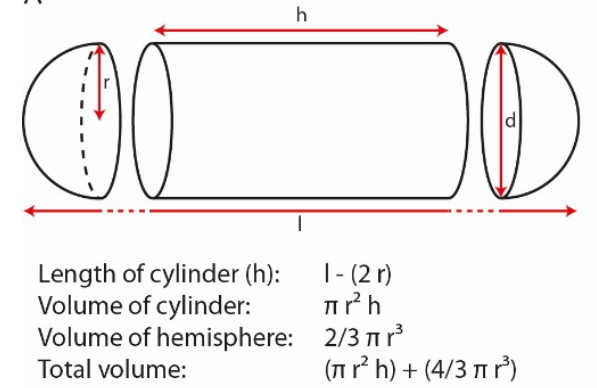

B

\begin{tabular}{ll}
\hline E. coli: Single cell dimensions \\
\hline number of bacteria at $\mathrm{OD}_{600 \mathrm{~mm}}=1^{*}$ & $7.8 \times 10^{8} / \mathrm{ml}$ \\
\hline Diameter $(\mathrm{d}){ }^{*}$ & $1,3 \mu \mathrm{m}$ \\
Radius $(\mathrm{r})=\mathrm{d} / 2$ & $0,65 \mu \mathrm{m}$ \\
Total length $(\mathrm{I}){ }^{*}$ & $3,9 \mu \mathrm{m}$ \\
Length cylinder (h) & $2,6 \mu \mathrm{m}$ \\
\hline Thickness OM (a) ${ }^{* *}$ & $0,007 \mu \mathrm{m}$ \\
Thickness PP (b) ${ }^{* *}$ & $0,021 \mu \mathrm{m}$ \\
Thickness IM (c) ${ }^{* *}$ & $0,006 \mu \mathrm{m}$
\end{tabular}

C

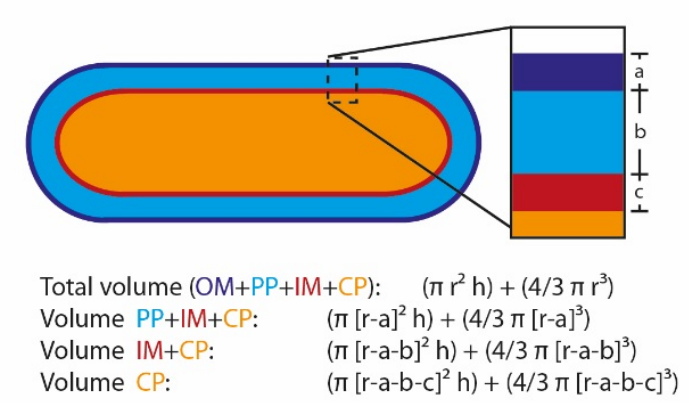

D

\begin{tabular}{lccc}
\hline \multicolumn{3}{l}{ E. coli: Volumes of Subcompartments } \\
& single cell & \multicolumn{3}{c}{$3.9 \times 10^{9}$ cells } \\
\cline { 2 - 4 } Total volume $(\mathrm{OM}+\mathrm{PP}+\mathrm{IM}+\mathrm{CP})$ & $4,60 \mu \mathrm{m}^{3}$ & $1,79 \times 10^{10} \mu \mathrm{m}^{3}$ & $17,9 \mu \mathrm{I}$ \\
Volume PP+IM+CP & $4,49 \mu \mathrm{m}^{3}$ & $1,75 \times 10^{10} \mu \mathrm{m}^{3}$ & $17,5 \mu \mathrm{l}$ \\
Volume IM+CP & $4,17 \mu \mathrm{m}^{3}$ & $1,63 \times 10^{10} \mu \mathrm{m}^{3}$ & $16,3 \mu \mathrm{l}$ \\
Volume CP & $4,08 \mu \mathrm{m}^{3}$ & $1,59 \times 10^{10} \mu \mathrm{m}^{3}$ & $15,9 \mu \mathrm{l}$ \\
Volume OM & $0,11 \mu \mathrm{m}^{3}$ & $4,32 \times 10^{8} \mu \mathrm{m}^{3}$ & $0,43 \mu \mathrm{l}$ \\
Volume PP & $0,32 \mu \mathrm{m}^{3}$ & $1,26 \times 10^{9} \mu \mathrm{m}^{3}$ & $1,26 \mu \mathrm{l}$ \\
Volume IM & $0,09 \mu \mathrm{m}^{3}$ & $3,49 \times 10^{8} \mu \mathrm{m}^{3}$ & $0,35 \mu \mathrm{l}$ \\
Volume IM+OM & $0,20 \mu \mathrm{m}^{3}$ & $7,81 \times 10^{8} \mu \mathrm{m}^{3}$ & $0,78 \mu \mathrm{l}$
\end{tabular}

Figure 3: Calculation of subcellular compartment dimensions of $E$. coli. (A) For subsequent calculations, the shape of a single $E$. coli cell was abstracted and considered as a cylinder flanked by two hemispheres. (B) Cell dimensions of a single E. coli BW25113 cell cultured in LB-medium as reported in literature. *Values taken from Volkmer and Heinemann (Volkmer and Heinemann, 2011). **Values taken from Matias et al. (Matias et al., 2003). (C) Model depicting the distribution of bacterial compartments and the equations used for calculating their volumes. (D) Volumes of bacterial compartments calculated by using parameters and equations depicted in (B) and (C). The number of $3.9 \times 10^{9}$ cells corresponds to $5 \mathrm{ml}$ LB-medium culture of $E$. coli BW25113 which we used for our experimental setup. 


\section{Uptake of ciprofloxacin}

The absolute amounts of CIP internalized by $3.9 \times 10^{9}$ cells of wildtype $E$. coli at $37^{\circ} \mathrm{C}$ are depicted in Figure 4A (white bars). The sum of amounts across all fractions corresponds well to the amount of CIP found in whole cell lysates (750 pg [ $\pm 35 \mathrm{pg}]$ ). The bulk amount of CIP (592 pg [ $\pm 50 \mathrm{pg}]$ ) was recovered in the $\mathrm{CP}$ of the cells, while lower amounts were present in the PP (277 pg [ $\pm 13 \mathrm{pg}]$ ) and the $\mathrm{M}$ fraction (45 pg [ $\pm 33 \mathrm{pg}]$ ). Interestingly, when calculating the actual concentration of CIP in the distinct fractions, we found that with $221 \mathrm{pg} / \mu \mathrm{l}[ \pm 10 \mathrm{pg} / \mu \mathrm{l}]$, the highest concentration is reached in the PP, while the CP has $37 \mathrm{pg} / \mu \mathrm{l}[ \pm 3 \mathrm{pg} / \mu \mathrm{l}]$ and the $\mathrm{M}$ fraction has $57 \mathrm{pg} / \mu \mathrm{l}[ \pm 42 \mathrm{pg} / \mu \mathrm{l}]$. Given the fact that the compound first has to pass the PP before it reaches the $\mathrm{CP}$, we hypothesized that a fully equilibrated partition of CIP may not be achieved in the 10 min time window of the experiment, and more CIP might reach the CP at longer times. This was supported by the influence of diminished temperature on the uptake of CIP. When the bacteria were subjected to $100 \mathrm{ng} / \mathrm{ml} \mathrm{CIP}$ for $10 \mathrm{~min}$ at $4^{\circ} \mathrm{C}$, we found less CIP in all fractions compared to the values obtained at $37^{\circ} \mathrm{C}$ (Figure 4B). We attribute this effect to lower diffusion rates. However, with $147 \mathrm{pg}[ \pm 73 \mathrm{pg}]$ most of the CIP was recovered in the PP of the cells, which is only 2 -fold lower than at $37^{\circ} \mathrm{C}$. In contrast, the $\mathrm{CP}$ only held $91 \mathrm{pg}[ \pm 21 \mathrm{pg}]$ which is approx. 6.5 -fold lower than at $37^{\circ} \mathrm{C}$. Thus, at lower temperatures the amount of CIP accumulating in the CP was drastically decreased when compared to the uptake at $37^{\circ} \mathrm{C}$, whereas the amounts of CIP in the PP are less affected. Hence the IM seems to represent a tighter barrier for diffusion mediated CIP uptake than the OM. To further assess the rate of uptake, the amount of CIP in fractions was quantified at five different time points between 0 and 30 minutes. $\mathrm{A}$ constant increase of uptake up to the 10 min-time point was observed for all compartments, but the 30 min time point did neither exhibit an additional uptake or a shift in CP/PP ratios.

The distribution of CIP internalized by the TolC-deficient E. coli (Figure 4, gray bars) was similar to the wildtype strain (white bars), but the overall amounts were 2 - 4-fold higher: In the CP, $1974 \mathrm{pg}$ [ $\pm 236 \mathrm{pg}]$ were detected, and the amounts in PP and $M$ fractions were $402 \mathrm{pg}[ \pm 19 \mathrm{pg}]$ and $133 \mathrm{pg}$ [ $\pm 53 \mathrm{pg}$ ], respectively (Supplementary Table S2). This suggests that CIP is exported from E. coli wildtype in substantial amounts by means of the AcrAB-TolC efflux system. In line with these observations, the MIC of CIP was $10 \mathrm{ng} / \mathrm{ml}$ for the wildtype E. coli, whereas for the TolC-deficient strain we determined an MIC of $3 \mathrm{ng} / \mathrm{ml}$. The values correlate well with previous observations ${ }^{37-39}$. Finally, the amount of CIP in whole cell lysates was determined in E. coli $\Delta$ TolC being challenged with CIP concentrations over a range of $25-3200 \mathrm{ng} / \mathrm{ml}$. CIP uptake was found to be linear over that concentration range with a coefficient of determination $\left(R^{2}\right)$ of 0.97 (Figure $S 3$ ). 

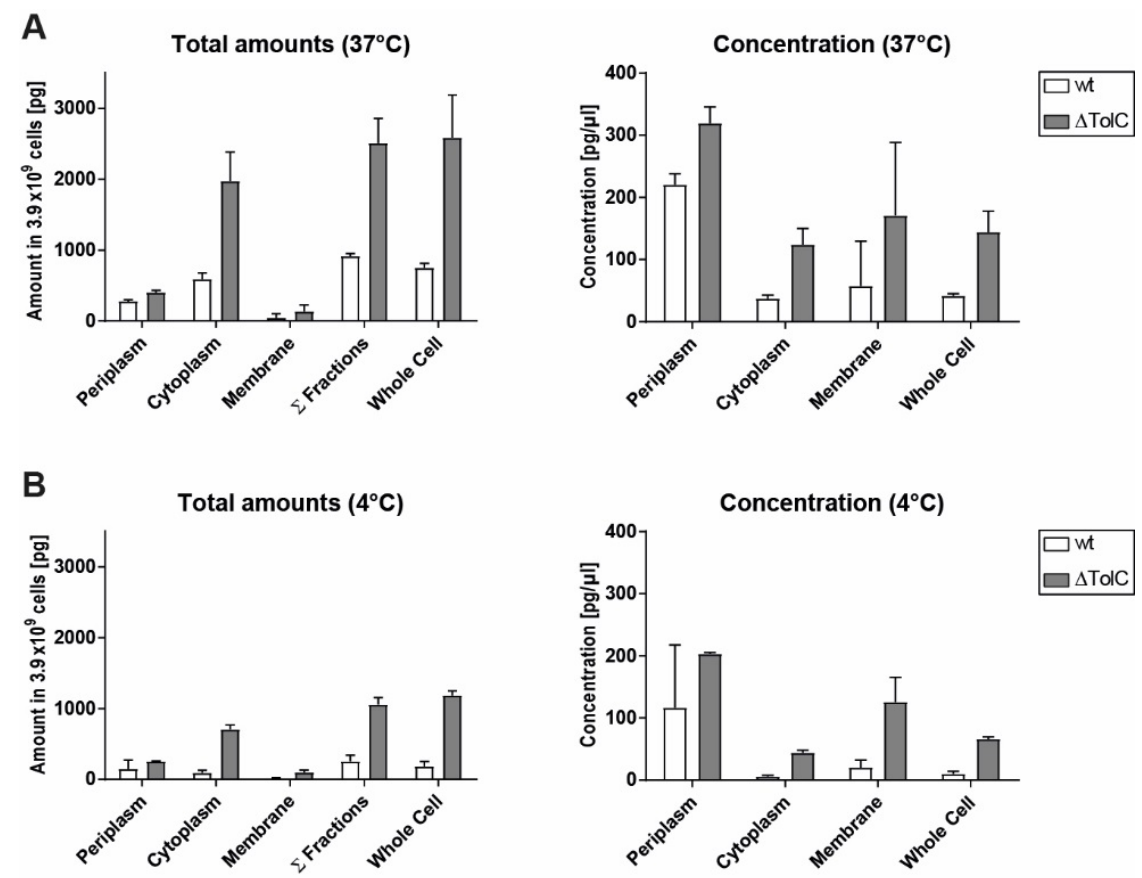

C
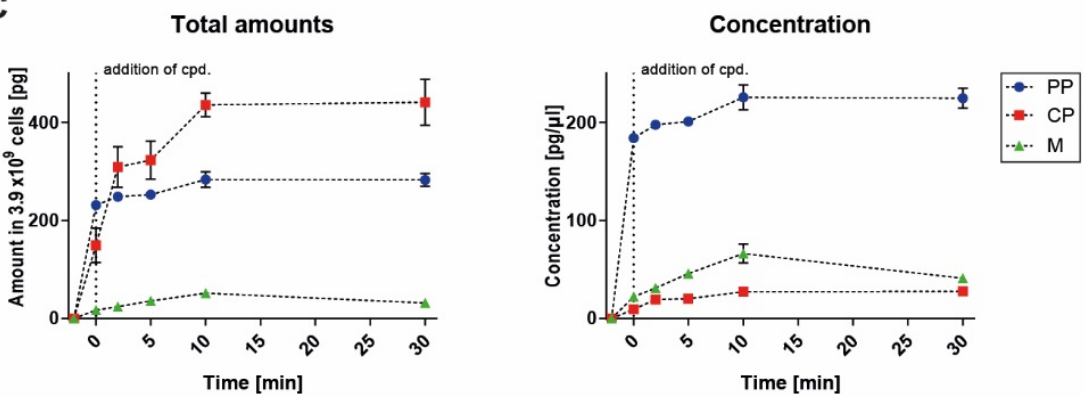

Figure 4: Quantification of ciprofloxacin in subcellular compartments of $E$. coli. Concentrations were calculated according to Figure. 3. (A) Amount and concentration of CIP in subcellular compartments of E. coli wildtype or $\Delta$ TolC. Cells were subjected to $100 \mathrm{ng} / \mathrm{ml} \mathrm{CIP}$ for 10 min at $37^{\circ} \mathrm{C}$ and subsequently processed for fractionation and LC/MS analysis. " $\Sigma$ Fractions" denotes the cumulated amounts determined in periplasm, cytoplasm and membranes. Whole cell is the amount found in unfractionated bacteria. (B) Same experiment as in (A) performed at $4^{\circ} \mathrm{C}$. (C) Wildtype E. coli was treated with $100 \mathrm{ng} / \mathrm{ml} \mathrm{CIP}$ at $37^{\circ} \mathrm{C}$, and subcellular fractionation was performed at indicated timepoints. Timepoint " $0 \mathrm{~min}$ " indicates that bacteria were immediately processed after addition of CIP. Timepoint "- $2.5 \mathrm{~min}$ " is the value obtained from untreated bacteria.

\section{Uptake of trimethoprim, tetracycline and erythromycin}

In subsequent experiments, the uptake of the antibiotics trimethoprim (TMP), tetracycline (TET) and erythromycin (ERY) was quantified. For TMP we found $130 \mathrm{pg}[ \pm 19 \mathrm{pg}]$ in the PP and $356 \mathrm{pg}[ \pm 16 \mathrm{pg}]$ in the $\mathrm{CP}$ of $3.9 \times 10^{9}$ wildtype E. coli cells, while no compound was detectable in the membranous fraction (Figure 5A). Interestingly, the amounts quantified in the TolC-deficient strain were only marginally higher with $130 \mathrm{pg}[ \pm 7 \mathrm{pg}]$ in the PP and $460 \mathrm{pg}[ \pm 73 \mathrm{pg}]$ in the $\mathrm{CP}$, indicating that TMP is not as prone to AcrAB-TolC-mediated efflux as CIP. This observation is in line with the MIC recorded for TMP (Table 1), which was nearly equal for the wildtype $(0.056 \mu \mathrm{g} / \mathrm{ml}$ ) and the TolC-deficient strain $(0.041 \mu \mathrm{g} / \mathrm{ml})$. 
In case of TET, comparably high amounts of antibiotic were detected in the single fractions (Figure $5 \mathrm{~B})$. For the wildtype $629 \mathrm{pg}[ \pm 73 \mathrm{pg}]$ were quantified in the PP, $4451 \mathrm{pg}[ \pm 435 \mathrm{pg}]$ in the CP and $610 \mathrm{pg}[ \pm 25 \mathrm{pg}]$ in the M-fraction while for the TolC-mutant the values were $772 \mathrm{pg}[ \pm 62 \mathrm{pg}], 4274 \mathrm{pg}$ $[ \pm 677 \mathrm{pg}]$ and $785 \mathrm{pg}[ \pm 100 \mathrm{pg}]$, respectively. Hence, again there was not a pronounced difference in the accumulation of compound in the wildtype and the TolC-mutants. The equal amount of uptake was not fully reflected by the MIC-values, which were approx. 2-fold lower for the TolC-mutant $(0.69 \mu \mathrm{g} / \mathrm{ml})$ compared to the wildtype $(1.55 \mu \mathrm{g} / \mathrm{ml})$, in accordance with previous observations ${ }^{40}$.

This phenomenon was even more pronounced with regard to ERY-uptake (Figure $5 \mathrm{C}$ ). It is known that the macrolide ERY shows only marginal activity against Gram-negative bacteria. Among clinical E. coli isolates, MICs ranging from $16 \mu \mathrm{g} / \mathrm{ml}$ to $1024 \mu \mathrm{g} / \mathrm{ml}$ have been reported ${ }^{41-42}$, whereas MICs range from $4 \mu \mathrm{g} / \mathrm{ml}$ to $150 \mu \mathrm{g} / \mathrm{ml}$ for lab strains ${ }^{38,43-44}$. For the $E$. coli wildtype strain, we recorded a MIC of $32.9 \mu \mathrm{g} / \mathrm{ml}$. The corresponding TolC-deficient strain showed a 55 -fold lower MIC of $0.63 \mu \mathrm{g} / \mathrm{ml}$, underlining the (known) susceptibility of ERY to AcrAB-TolC-mediated efflux ${ }^{43}$. This pronounced difference was not reflected by the uptake of ERY after $10 \mathrm{~min}$ incubation with the cells. ERY accumulated mainly in the CP. After $10 \mathrm{~min}$, a quantity of $230 \mathrm{pg}[ \pm 25 \mathrm{pg}]$ was found in the CP of $3.9 \times 10^{9}$ wildtype E. coli cells, but the values for the TolC-mutant were only 2.3 -fold higher $(530 \mathrm{pg}$ $\pm 40 \mathrm{pg}$ ). We speculated that the different time scales of the experiments (10 min for the uptake assay vs. $18 \mathrm{~h}$ for an MIC test) might account for the non-coherent relative differences between uptake and MIC potentiation. As concentrations of $100 \mathrm{ng} / \mathrm{ml}$ ERY are not harmful for E. coli cells, we prolonged the antibiotic exposure and quantified the subcellular uptake at six different time points (10 min, 1h, 3h, 6h, 12h, 24h). Both strains were not impaired in growth under these conditions. The overall amount of intracellular ERY increased continuously over that time range from $273 \mathrm{pg}$ [ $\pm 28 \mathrm{pg}]$ after $10 \mathrm{~min}$ to $3840 \mathrm{pg}[ \pm 213 \mathrm{pg}]$ after $24 \mathrm{~h}$ in the wild type (Figure $5 \mathrm{C}$ ). The fraction of ERY in the CP increased from $84 \%$ (10 $\mathrm{min})$ to $97 \%(24 \mathrm{~h})$ of the sum of all fractions. Surprisingly, the relative differences in uptake of the $\Delta$ TolC strain vs. the wild type first increased from 2 fold $(10 \mathrm{~min})$ to 8.5 fold ( $3 \mathrm{~h}$ ), but decreased at later time points. After $24 \mathrm{~h}$, both strains internalized almost equal quantities of ERY. Thus, the integral total exposure to ERY over time was higher for the $\triangle$ TolC strain than for the wild type, but the relative ratio of accumulation was not constant.

To get further insights on the kinetics of uptake of CIP, TET, and TMP at timescales up to $45 \mathrm{~min}$, we quantified their amount with unfractionated cells in a 96 well, filter plate assay (Supplementary Figure S4). The quantities of antibiotics obtained by this different protocol matched well with those of the fractionation procedure. While a clear difference in uptake between WT and $\triangle T$ TolC strain was found for CIP, the uptake of TET and TMP was almost identical between the two strains. 
A

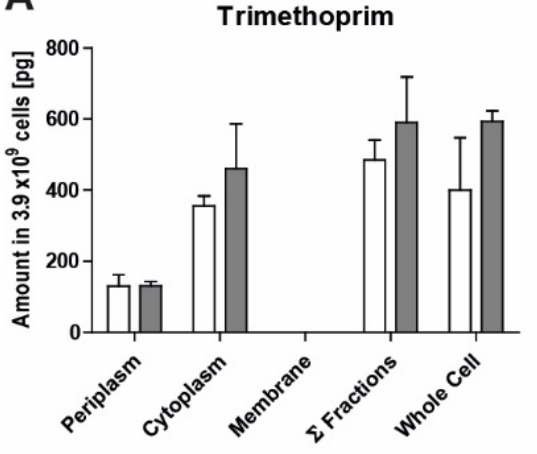

C

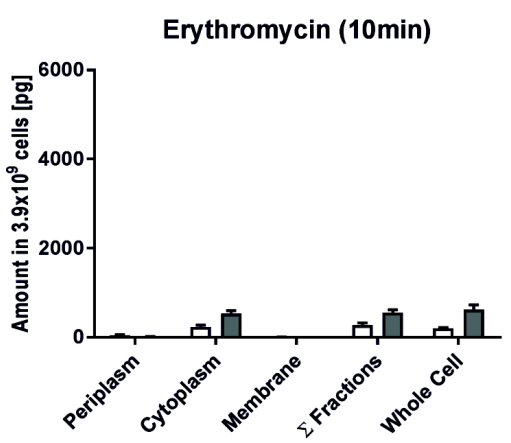

Erythromycin (3h)

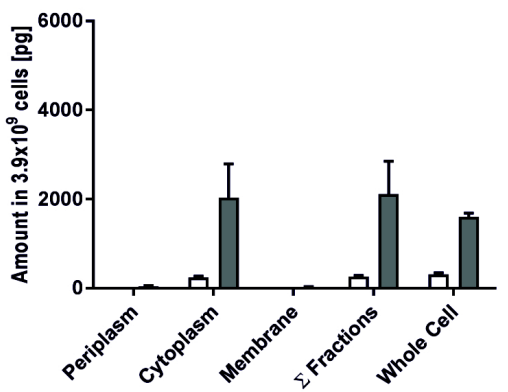

Erythromycin (12h)

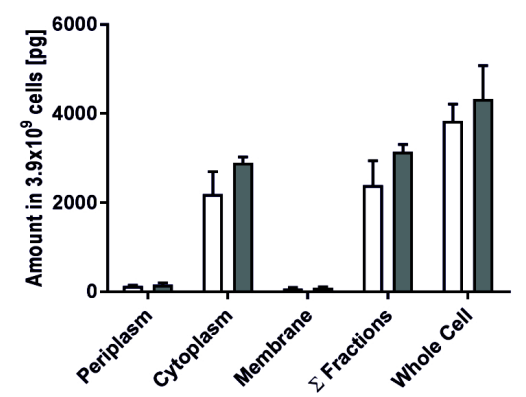

B

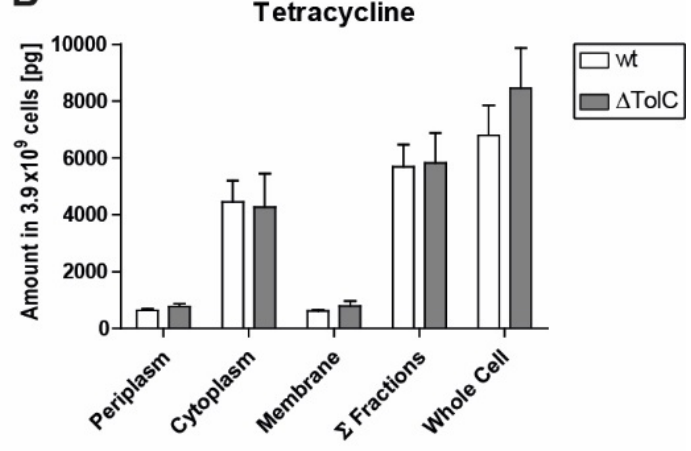

Erythromycin (1h)

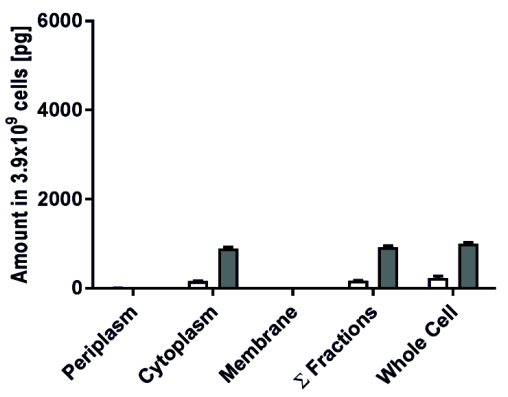

Erythromycin (6h)

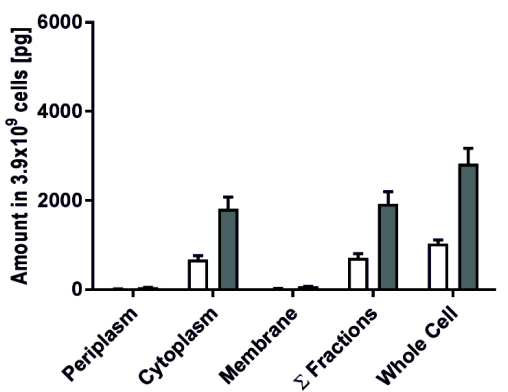

Erythromycin (24h)

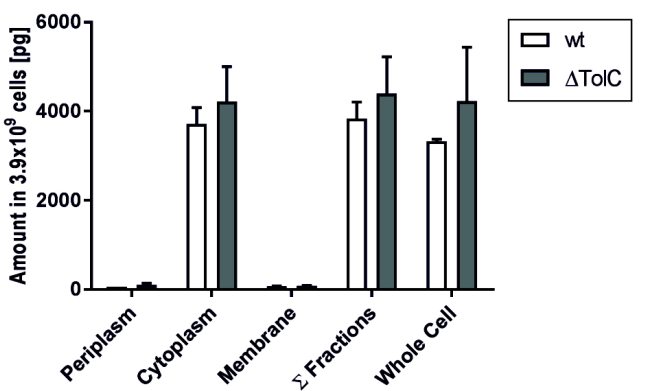

Figure 5: Quantification of Trimethoprim, Tetracycline and Erythromycin in subcellular compartments of $\boldsymbol{E}$. coli. Amounts of (A) TMP, (B) TET and (C) ERY in subcellular compartments of $E$. coli wildtype or $\Delta$ TolC. Cells were subjected to $100 \mathrm{ng} / \mathrm{ml}$ of respective antibiotic at $37^{\circ} \mathrm{C}$. The incubation time was $10 \mathrm{~min}$ for TMP and TET, while 6 time points (10 min, 1h, 3h, 6h, 12h, 24h) were recorded for ERY. 
$\mathrm{MIC}$ in $\mu \mathrm{g} / \mathrm{ml}$

wildtype $\Delta$ TolC

CIP $\quad 0.010 \quad 0.003$

$\begin{array}{lll}\text { TMP } & 0.056 & 0.041\end{array}$

TET $\quad 1.55 \quad 0.69$

ERY $\quad 32.9 \quad 0.63$

\section{Discussion}

In the present study we designed a mass-spectrometry-based assay, which allows for quantification of drug-internalization by Gram-negative bacterial cells with subcompartmental resolution. This versatile approach overcomes limitations of methods that rely on fluorescent or radiolabels and is applicable to a broad spectrum of chemical compounds. Similar assays have already been applied in various investigations in order to measure small molecule-accumulation by LC-MS ${ }^{20-21,23-24}$. However, to elucidate whether a given drug reaches its desired target, quantitative measurements of their accumulation in distinct cell compartments are beneficial. Bacterial subfractionation proved to be a powerful tool, which we combined with LC-MS-analyses. By adding slight modifications to wellestablished protocols we could reach adequate purities of the bacterial subfractions. As previously stated by Thein et al., ${ }^{26}$ a perfect separation of proteins from different bacterial compartments is not possible. Thus, the data interpretation should consider that the subfractions represent a strong enrichment of molecules of the respective compartment rather than a complete separation. In addition, it cannot be ruled out that small molecule antibiotics re-distribute to a stronger degree than the marker proteins between the fractions during the fractionation procedure. However, various observations indicate that the degree of re-distribution is limited: As the periplasm is released first into a large volume, a diffusion of antibiotic into the periplasm fraction would be expected. However, the majority of substance was found in the cytoplasm for all antibiotics, implying that such diffusion is limited. In addition, the time-dependent uptake curves into bacterial fractions (Figure 5C) exhibit defined, continuous curve shapes that are not superseded by a re-distribution upon fractionation.

Another limitation concerns compounds that bind covalently to their target. Those are not amenable to our current analytical method, that relies on the quantification of the free drug after precipitating noncovalently bound protein targets. This includes the important class of $\beta$-lactam antibiotics, for which we observed large standard deviations and a trend of quickly decreasing free drug concentrations over $30 \mathrm{~min}$. But even for noncovalently binding antibiotics, the protein precipitation 
step is a potential source of analyte loss, as in many other bioanalytical methods. In terms of scale, the protocol presented herein was optimized for bacterial culture volumes of $5 \mathrm{ml}$, which is smaller than that of bacterial fractionation assays described elsewhere, with culture volumes ranging from $25 \mathrm{ml}$ to $1 \mathrm{I}^{26,45-46}$. This allows for conduction of the assay in a micro test tube-format, with more samples being processed in parallel.

Starting with ciprofloxacin, we observed $750 \mathrm{pg}$ in $3.9 \times 10^{9}$ wildtype $E$. coli cells after $10 \mathrm{~min}$ of incubation. In the TolC-efflux pump mutant the accumulation was $2588 \mathrm{pg}$. These values correlate very well with the ones found in a recent study by Vergalli et al., who quantified bacterial CIP accumulation by means of spectrofluorimetry on a single cell level ${ }^{39}$. In their study, E. coli cells were incubated in presence of $2 \mu \mathrm{g} / \mathrm{ml} \mathrm{CIP}$ for $5 \mathrm{~min}$. During this period, a single wildtype cell accumulated $0.82 \times 10^{-5} \mathrm{pg}$ antibiotic, while an efflux pump-deficient cell $(\triangle A c r A B)$ accumulated $1.5 \times 10^{-5} \mathrm{pg}$. The amounts changed only marginally after $15 \mathrm{~min}$ of incubation. To compare these observations to our findings, the values have to be multiplied with $3.9 \times 10^{9}$ to match the cell number. Further, the bacteria in our study were challenged with 20 -fold lower CIP concentrations, so a factor of has to be considered. The respectively approximated amounts are $1230 \mathrm{pg}$ for the wildtype and $2250 \mathrm{pg}$ for the AcrAB-mutant. Another study conducted by Oethinger et al. made use of scintillation counting, i.e. E. coli cells were challenged with $10 \mu \mathrm{M}(=3.31 \mu \mathrm{g} / \mathrm{ml}){ }^{14} \mathrm{C}$-labeled CIP ${ }^{40}$. The CIP-accumulation reached a plateau after 5 min incubation, similar to our observations. The net-uptake quantified for the wildtype strain was $103 \mathrm{pmol} \mathrm{CIP} / 10^{9}$ cells, which equal $1.33 \times 10^{5} \mathrm{pg} \mathrm{CIP} / 3.9 \times 10^{9}$ cells. We applied a factor of 0.03 to adjust this amount for the $100 \mathrm{ng} / \mathrm{ml}$ initial CIP concentration used in our study. Such an extrapolation appears valid for the purpose of comparing these studies, because we found that the uptake of CIP was linear between 25 and $3200 \mathrm{ng} / \mathrm{ml}$ (Figure S3). Eventually, the approximated CIP amounts accumulated are $4017 \mathrm{pg}$ for the wildtype and approx. $9000 \mathrm{pg}$ for an AcrAB-mutant. In line with our findings, the ratio between wildtype and efflux pump mutant was found to be approx. 2-fold. However, the overall amounts differ by a factor of four from the values determined by us. Yet, this discrepancy can be explained by the numerous technical differences in sample processing and readout procedures between the protocol of Oethinger et al. and our experimental setup.

Interestingly, the conversion of antibiotic amounts in subcompartments to actual intracellular compound concentrations demonstrates that CIP was not homogenously distributed throughout the bacterial subcompartments: Although the bulk amount of CIP was detected in the cytoplasm, the highest CIP concentration was prevalent in the periplasm. This highlights the difference between the quantitative amount of a given compound vs its actual concentration in the bacterial compartments. As an internal control, we compared the summed amount of antibiotic from all fractions with the amount obtained from unfractionated whole cells, and found a good overall agreement between the numbers. This indicates that the fractionation procedure is not associated with substantial compound losses, e.g. during the washing steps.

We also assessed tetracycline accumulation in E. coli. Remarkably, TET accumulated in the cytoplasm to a much greater extent than CIP (4451 pg (TET) vs. $592 \mathrm{pg}$ (CIP) in E. coli WT) even though CIP proved to be a more potent antibiotic than TET based on their MIC-values $(1.55 \mu \mathrm{g} / \mathrm{ml}$ (TET) vs. $0.010 \mu \mathrm{g} / \mathrm{ml}$ (CIP) in E. coli wildtype). Regarding their target-binding abilities, TET and CIP have been shown to exhibit similar properties: TET is known to have at least one binding site on its target, the $70 \mathrm{~S}$ ribosome, with apparent binding constants of $1-30 \mu \mathrm{M}^{47-48}$ while ciprofloxacin binds to its target DNA-gyrase with a constant of approximately $4 \mu \mathrm{M}^{49}$. However, given that a single $E$. coli cell 
hosts $1,500-2,000$ Gyrase $A_{2} B_{2}$ tetramers ${ }^{50}$, but about 27,000 ribosomes ${ }^{51}$ would lead to the simple theoretical assumption, that TET-amounts have to be 10 -fold higher than CIP-amounts in order to hit all respective target molecules.

For TET and ERY, differences in MICs between WT and TolC mutant strains were not reflected by equal differences in uptake. A time course of ERY uptake over $24 \mathrm{~h}$ revealed that the integral uptake was higher in the $\triangle$ TolC mutant than in the wildtype, and that the relative ratio changed over time. This implies that bacterial uptake is not mediated by a static arsenal of constitutively operating import and export proteins, but dynamically regulated over time. Thus, there is no simple 1:1 relationship between uptake ratios at single time points and MIC ratios. The antibiotic efficacy of small molecules is further dependent on additional parameters like target binding kinetics, target abundance, off-target effects or long-term stability. Furthermore, the vulnerability of the cell towards a given mechanisms of action, i.e. the required \%age of target/pathway inhibition to induce cell death, can vastly differ. Such mechanistic data are not known so far, but mandatory for an accurate prediction of antibiotic efficacy. However, intracellular concentration measurements, as reported in this study, provide an important and essential piece of information for future quantitative cellular models of antibiotic efficacy, and for supporting today's antibiotic lead optimization programs.

\section{Conclusion}

In this work, a versatile method for the determination of compound concentrations in three bacterial compartments based on an optimized fractionation protocol in combination with LC-MS/MS quantification is presented. We found that standard antibiotics distribute unevenly across the periplasm, cytoplasm and membranes. The extent of intracellular accumulation correlated with their growth inhibitory properties in some, but not in all cases. This demonstrates that additional experimental data (e.g. on quantitative drug-target engagement) are required for a full rational understanding of antibiotic efficacy. However, the antibiotic concentration the compartment where the drug target is expressed constitutes an essential piece of information for a more rational optimization of novel antibiotics against Gram-negative infections. An adaptation of the method to a larger set of clinical and lab mutants of a given species, to other bacterial pathogens, and to a larger set of structurally different antibiotic leads appears to be an attractive topic of future studies. 


\section{Acknowledgement}

We would like to thank Ulrike Beutling for technical support and many helpful discussions. The research leading to the results discussed here was conducted as part of the translocation consortium (www.translocation.eu) and has received support from the Innovative Medicines Initiative Joint Undertaking under grant agreement no. 115525 of the European Union's seventh framework program (FP/2007-2013).

\section{Author contributions}

HP and SKH conducted the experiments.

$\mathrm{HP}, \mathrm{VF}$ and $\mathrm{MB}$ conceived the study and wrote the manuscript.

MGR established the whole cell plate based quantification assay and CFU count assay.

AH established the first version of the fractionation assay.

\section{Supporting Information}

Quantification data, calibration curves, instrument parameters, microbiological experiments, and additional kinetic experiments are supplied as Supporting Information. 


\section{References}

1. WHO Antimicrobial resistance: global report on surveillance; WHO Press, 2014.

2. Baur, D.; Gladstone, B. P.; Burkert, F.; Carrara, E.; Foschi, F.; Dobele, S.; Tacconelli, E., Effect of antibiotic stewardship on the incidence of infection and colonisation with antibiotic-resistant bacteria and Clostridium difficile infection: a systematic review and meta-analysis. Lancet. Infect. Dis. 2017, 17 (9), 990-1001.

3. Nikaido, H.; Vaara, M., Molecular basis of bacterial outer membrane permeability. Microbiol. Rev. 1985, 49 (1), 1-32.

4. Henderson, J. C.; Zimmerman, S. M.; Crofts, A. A.; Boll, J. M.; Kuhns, L. G.; Herrera, C. M.; Trent, M. S., The Power of Asymmetry: Architecture and Assembly of the Gram-Negative Outer Membrane Lipid Bilayer. Annu. Rev. Microbiol. 2016, 70, 255-78.

5. Delcour, A. H., Outer membrane permeability and antibiotic resistance. Biochim. Biophys. Acta 2009, 1794 (5), 808-16.

6. Pages, J. M.; James, C. E.; Winterhalter, M., The porin and the permeating antibiotic: a selective diffusion barrier in Gram-negative bacteria. Nat. Rev. Microbiol. 2008, 6 (12), 893-903.

7. Nikaido, H., Molecular basis of bacterial outer membrane permeability revisited. Microbiol. Mol. Biol. Rev. 2003, 67 (4), 593-656.

8. O'Shea, R.; Moser, H. E., Physicochemical properties of antibacterial compounds: implications for drug discovery. J. Med. Chem. 2008, 51 (10), 2871-8.

9. Ferguson, A. D.; Deisenhofer, J., TonB-dependent receptors-structural perspectives. Biochim. Biophys. Acta 2002, 1565 (2), 318-32.

10. Gorska, A.; Sloderbach, A.; Marszall, M. P., Siderophore-drug complexes: potential medicinal applications of the 'Trojan horse' strategy. Trends Pharmacol. Sci. 2014, 35 (9), 442-9.

11. Graef, F.; Richter, R.; Fetz, V.; Murgia, X.; De Rossi, C.; Schneider-Daum, N.; Allegretta, G.; Elgaher, W.; Haupenthal, J.; Empting, M.; Beckmann, F.; Bronstrup, M.; Hartmann, R.; Gordon, S.; Lehr, C. M., In Vitro Model of the Gram-Negative Bacterial Cell Envelope for Investigation of AntiInfective Permeation Kinetics. ACS Infect. Dis. 2018. 
12. Wilson, D. N., Ribosome-targeting antibiotics and mechanisms of bacterial resistance. Nat. Rev. Microbiol. 2014, 12 (1), 35-48.

13. Piddock, L. J., Multidrug-resistance efflux pumps - not just for resistance. Nat. Rev. Microbiol. 2006, 4 (8), 629-36.

14. Tommasi, R.; Brown, D. G.; Walkup, G. K.; Manchester, J. I.; Miller, A. A., ESKAPEing the labyrinth of antibacterial discovery. Nat. Rev. Drug Discov. 2015, 14 (8), 529-542.

15. Payne, D. J.; Gwynn, M. N.; Holmes, D. J.; Pompliano, D. L., Drugs for bad bugs: confronting the challenges of antibacterial discovery. Nat. Rev. Drug Discov. 2007, 6 (1), 29-40.

16. Silver, L. L., A Gestalt approach to Gram-negative entry. Bioorg. Med. Chem. 2016, 24 (24), 6379-6389.

17. Zgurskaya, H. I.; Lopez, C. A.; Gnanakaran, S., Permeability Barrier of Gram-Negative Cell Envelopes and Approaches To Bypass It. ACS Infect. Dis. 2015, 1 (11), 512-522.

18. Tommasi, R.; lyer, R.; Miller, A. A., Antibacterial Drug Discovery: Some Assembly Required. ACS Infect. Dis. 2018, 4 (5), 686-695.

19. Tian, H.; Six, D. A.; Krucker, T.; Leeds, J. A.; Winograd, N., Subcellular Chemical Imaging of Antibiotics in Single Bacteria Using C60-Secondary Ion Mass Spectrometry. Anal. Chem. 2017, 89 (9), 5050-5057.

20. Bhat, J.; Narayan, A.; Venkatraman, J.; Chatterji, M., LC-MS based assay to measure intracellular compound levels in Mycobacterium smegmatis: linking compound levels to cellular potency. J. Microbiol. Methods. 2013, 94 (2), 152-8.

21. Cai, H.; Rose, K.; Liang, L. H.; Dunham, S.; Stover, C., Development of a liquid chromatography/mass spectrometry-based drug accumulation assay in Pseudomonas aeruginosa. Anal. Biochem. 2009, 385 (2), 321-5.

22. Phetsang, W.; Pelingon, R.; Butler, M. S.; Kc, S.; Pitt, M. E.; Kaeslin, G.; Cooper, M. A.; Blaskovich, M. A., Fluorescent Trimethoprim Conjugate Probes To Assess Drug Accumulation in Wild Type and Mutant Escherichia coli. ACS Infect. Dis. 2016, 2 (10), 688-701.

23. Davis, T. D.; Gerry, C. J.; Tan, D. S., General platform for systematic quantitative evaluation of small-molecule permeability in bacteria. ACS Chem. Biol. 2014, 9 (11), 2535-44.

24. Richter, M. F.; Drown, B. S.; Riley, A. P.; Garcia, A.; Shirai, T.; Svec, R. L.; Hergenrother, P. J., Predictive compound accumulation rules yield a broad-spectrum antibiotic. Nature 2017, 545 (7654), 299-304. 
25. Iyer, R.; Ye, Z.; Ferrari, A.; Duncan, L.; Tanudra, M. A.; Tsao, H.; Wang, T.; Gao, H.; Brummel, C. L.; Erwin, A. L., Evaluating LC-MS/MS To Measure Accumulation of Compounds within Bacteria. ACS Infect. Dis. 2018, 4 (9), 1336-1345.

26. Thein, M.; Sauer, G.; Paramasivam, N.; Grin, I.; Linke, D., Efficient subfractionation of gramnegative bacteria for proteomics studies. J. Proteome Res. 2010, 9 (12), 6135-47.

27. Neu, H. C.; Heppel, L. A., The release of enzymes from Escherichia coli by osmotic shock and during the formation of spheroplasts. J. Biol. Chem. 1965, 240 (9), 3685-92.

28. Ladner, C. L.; Yang, J.; Turner, R. J.; Edwards, R. A., Visible fluorescent detection of proteins in polyacrylamide gels without staining. Anal. Biochem. 2004, 326 (1), 13-20.

29. Lambert, R. J.; Pearson, J., Susceptibility testing: accurate and reproducible minimum inhibitory concentration (MIC) and non-inhibitory concentration (NIC) values. J. Appl. Microbiol. 2000, 88 (5), 784-90.

30. Garduno, R. A.; Faulkner, G.; Trevors, M. A.; Vats, N.; Hoffman, P. S., Immunolocalization of Hsp60 in Legionella pneumophila. J. Bacteriol. 1998, 180 (3), 505-13.

31. Feilmeier, B. J.; Iseminger, G.; Schroeder, D.; Webber, H.; Phillips, G. J., Green fluorescent protein functions as a reporter for protein localization in Escherichia coli. J. Bacteriol. 2000, 182 (14), 4068-76.

32. Abe, Y.; Haruta, I.; Yanagisawa, N.; Yagi, J., Mouse monoclonal antibody specific for outer membrane protein A of Escherichia coli. Monoclon. Antib. Immunodiagn. Immunother. 2013, 32 (1), 32-5.

33. Volkmer, B.; Heinemann, M., Condition-dependent cell volume and concentration of Escherichia coli to facilitate data conversion for systems biology modeling. PloS one 2011, 6 (7), e23126.

34. Heldal, M.; Norland, S.; Tumyr, O., X-ray microanalytic method for measurement of dry matter and elemental content of individual bacteria. Appl. Environ. Microbiol. 1985, 50 (5), 1251-7.

35. Pierucci, O., Dimensions of Escherichia coli at various growth rates: model for envelope growth. J. Bacteriol. 1978, 135 (2), 559-74.

36. Matias, V. R.; Al-Amoudi, A.; Dubochet, J.; Beveridge, T. J., Cryo-transmission electron microscopy of frozen-hydrated sections of Escherichia coli and Pseudomonas aeruginosa. J. Bacteriol. 2003, 185 (20), 6112-8. 
37. Aagaard, J.; Gasser, T.; Rhodes, P.; Madsen, P. O., MICs of ciprofloxacin and trimethoprim for Escherichia coli: influence of $\mathrm{pH}$, inoculum size and various body fluids. Infection 1991, 19 Suppl 3, S167-9.

38. Liu, A.; Tran, L.; Becket, E.; Lee, K.; Chinn, L.; Park, E.; Tran, K.; Miller, J. H., Antibiotic sensitivity profiles determined with an Escherichia coli gene knockout collection: generating an antibiotic bar code. Antimicrob. Agents Chemother. 2010, 54 (4), 1393-403.

39. Vergalli, J.; Dumont, E.; Cinquin, B.; Maigre, L.; Pajovic, J.; Bacque, E.; Mourez, M.; Refregiers, M.; Pages, J. M., Fluoroquinolone structure and translocation flux across bacterial membrane. Sci. Rep. 2017, 7 (1), 9821.

40. Oethinger, M.; Kern, W. V.; Jellen-Ritter, A. S.; McMurry, L. M.; Levy, S. B., Ineffectiveness of topoisomerase mutations in mediating clinically significant fluoroquinolone resistance in Escherichia coli in the absence of the AcrAB efflux pump. Antimicrob. Agents Chemother. 2000, 44 (1), 10-3.

41. Phuc Nguyen, M. C.; Woerther, P. L.; Bouvet, M.; Andremont, A.; Leclercq, R.; Canu, A., Escherichia coli as reservoir for macrolide resistance genes. Emerg. Infect. Dis. 2009, 15 (10), 164850.

42. Leng, B.; Meyers, B. R.; Hirschman, S. Z.; Keusch, G. T., Susceptibilities of gram-negative bacteria to combinations of antimicrobial agents in vitro. Antimicrob. Agents Chemother. 1975, 8 (2), 164-71.

43. Moore, S. D.; Sauer, R. T., Revisiting the mechanism of macrolide-antibiotic resistance mediated by ribosomal protein L22. Pro.c Natl. Acad. Sci. USA 2008, 105 (47), 18261-6.

44. Arthur, M.; Courvalin, P., Contribution of two different mechanisms to erythromycin resistance in Escherichia coli. Antimicrob. Agents. Chemother. 1986, 30 (5), 694-700.

45. Quan, S.; Hiniker, A.; Collet, J. F.; Bardwell, J. C., Isolation of bacteria envelope proteins. Methods Mol. Biol. 2013, 966, 359-66.

46. Imperi, F.; Ciccosanti, F.; Perdomo, A. B.; Tiburzi, F.; Mancone, C.; Alonzi, T.; Ascenzi, P.; Piacentini, M.; Visca, P.; Fimia, G. M., Analysis of the periplasmic proteome of Pseudomonas aeruginosa, a metabolically versatile opportunistic pathogen. Proteomics 2009, 9 (7), 1901-15.

47. Hlavka, J. J.; Boothe, J. H., The tetracyclines. Prog. Drug. Res. 1973, 17, 210-40.

48. Chukwudi, C. U., rRNA Binding Sites and the Molecular Mechanism of Action of the Tetracyclines. Antimicrob. Agents Chemother. 2016, 60 (8), 4433-41. 
49. Heddle, J.; Maxwell, A., Quinolone-binding pocket of DNA gyrase: role of GyrB. Antimicrob. Agents Chemother. 2002, 46 (6), 1805-15.

50. Soufi, B.; Krug, K.; Harst, A.; Macek, B., Characterization of the E. coli proteome and its modifications during growth and ethanol stress. Front. Microbiol. 2015, 6, 103.

51. Ortiz, J. O.; Forster, F.; Kurner, J.; Linaroudis, A. A.; Baumeister, W., Mapping 70 S ribosomes in intact cells by cryoelectron tomography and pattern recognition. J. Struct. Biol. 2006, 156 (2), 33441. 